\title{
Ultrasound findings in a patient with tuberculous epididymo-orchits
}

\author{
Dhilip Andrew (ㄷ) , Jovis Johny, Karthik Shyam 두
}

Radiology, St John's Medical College Hospital, Bangalore, Karnataka, India

Correspondence to Dr Karthik Shyam;

dr.karthikshyam@gmail.com

Accepted 26 October 2020

Check for updates

(C) BMJ Publishing Group Limited 2020. No commercial re-use. See rights and permissions. Published by BMJ.

To cite: Andrew D, Johny J, Shyam K. BMJ Case

Rep 2020;13:e237832.

doi:10.1136/bcr-2020-

237832

\section{DESCRIPTION}

A 40-year-old man presented to urology with progressive painless right hemiscrotal swelling of 1 month with no fever, trauma, weight loss or hernia. Local examination revealed right hemiscrotal swelling with hydrocele. Routine blood investigations were within normal limits, total count -6300 cells $/ \mathrm{mm}^{3}, \quad \mathrm{Hb}-12 \mathrm{~g} / \mathrm{dL}, \quad$ Fasting Blood Sugar $-90 \mathrm{mg} / \mathrm{dL}$ and creatinine of $0.9 \mathrm{mg} /$ dL. Patient had no significant medical, surgical or family history.

Ultrasound of the scrotum and testis revealed bulky right testis with well-defined, vascular, non-calcified hypoechoic lesion (figure 1A,B), on a background of multiple smallhypoechoic foci (figure 1C). Right epididymis was bulky, hypoechoic (figure 1D,E), and hypervascular (figure $1 \mathrm{~F}$ ). Minimal right hydrocele (figure $1 G$ ) was noted. Left testis was normal in size and vascularity (figure $1 \mathrm{H}$ ). Possibility of tuberculousepididymoorchitis was raised and was confirmed by Fine Needle Aspiration Cytology. Antitubercular treatment was initiated.

The most common extrapulmonary site of tuberculosis (TB) is the genitourinary tract (GUTB) (14\%-40\% of cases), which is the primary target of haematogenous dissemination. ${ }^{1}$ Two-thirds of cases of GUTB coexist with lower urinary tract involvement; isolated involvement is seen in 5\%-30\% cases. ${ }^{2}$ Spread from primary focus of infection can occur by haematogenous, lymphatic, canalicular and contiguous spread. ${ }^{3}$ Epididymis and vas deferens are the most commonly involved sites in GUTB. ${ }^{1}$ Retrocanalicular spread from prostate, and direct spread from kidney are the most common mechanisms causing epididymal $\mathrm{TB}^{4}{ }^{4}$ Isolated involvement of the testes is extremely rare; contiguous spread from epididymis is more common. ${ }^{1}$

High-resolution ultrasonography (HRUS) is the best modality for examination of scrotum, testis, epididymis and vas deferens. Ultrasonographic findings of GUTB are non-specific, and used to assess extent of disease and response to treatment. ${ }^{1}$ On HRUS, TB epididymitis can present as focal nodular lesion(s) in the tail. Other patterns include diffuse involvement of epididymis, and bipolar involvement, where both head and tail are involved. Majority of lesions are hypoechoic, but they can be heterogenous or hyperechoic. Lesion heterogeneity is due to fibrosis, granuloma, inflammatory oedema and caseation. Lesions can show mild hypervascularity on doppler, and can also progress into a complex abscess. ${ }^{1}$ On MRI, these lesions appear T2 hypointense, similar to tuberculous lesions

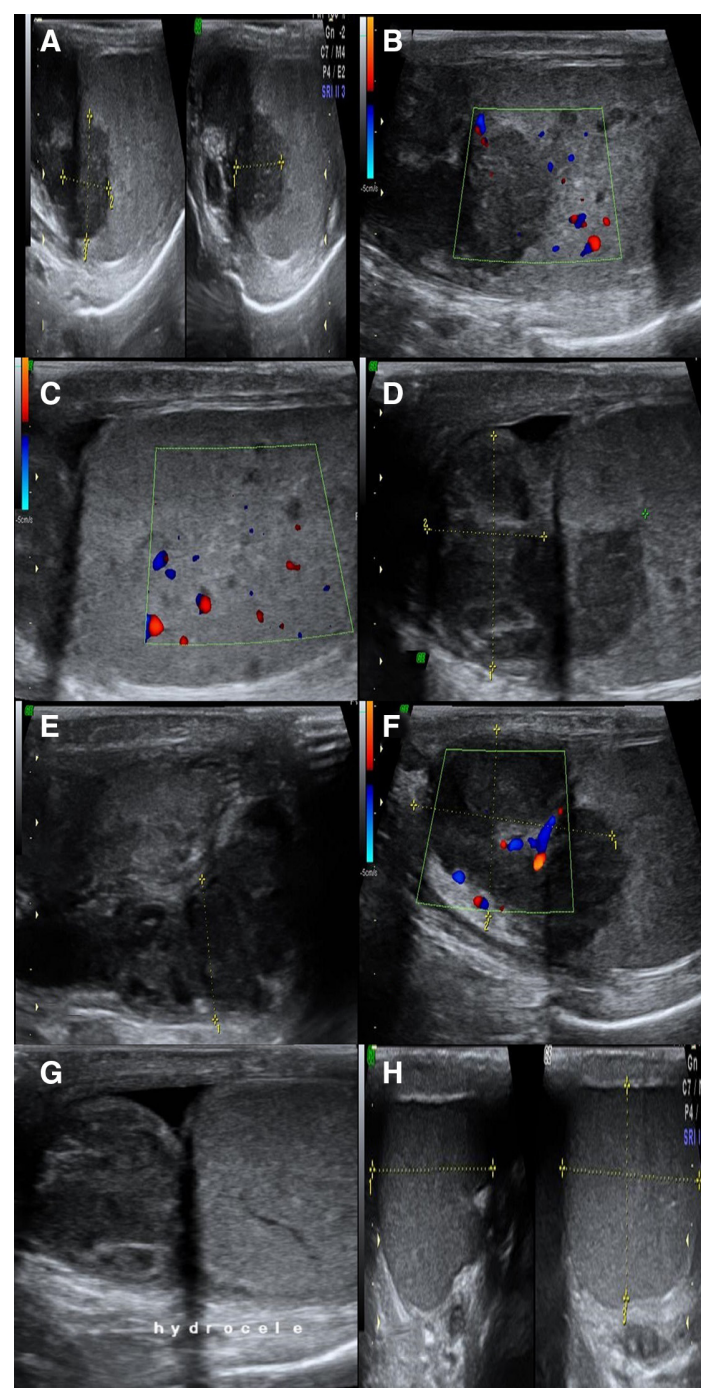

Figure 1 Ultrasound images of the bilateral testis. (A, B) Hypoechoic lesion in right testis with features of mild internal vascularity (white arrows). (C) Multiple small hypoechoic areas with increased vacularity within the right testis (white arrows). (D, E) Nodular enlarged and hypoechoic head and tail region of epididymis (white arrows). (F) Linear area of blood within involved region of epididymis. (G) Features of mild hydrocele. $(H)$ Left testis appears normal in size with normal echotexture and no hydrocele.

elsewhere. ${ }^{6}$ TB orchitis can show enlarged testis with heterogeneously hypoechoic echotexture; other patterns include nodular, enlarged, heterogenous hypoechoic testis and single or multiple, poorly or well-defined hypoechoic intratesticular lesions. $^{78}$ 
Differential diagnosis for TB epididymitis includes pyogenic epididymitis, which presents as a homogenous hypoechoic lesion with markedly hypervascularity. Presence of heterogeneous focal thickening of tail of epididymis $(>6 \mathrm{~mm})$ with features like testicular involvement, bilateral epididymal involvement, septate pyocele and scrotal wall sinuses favour tuberculous epididymitis. ${ }^{1}$ In case of isolated involvement of testis, malignancy needs to be considered as a differential. Malignant lesions are well defined and deform the contour of the testis. ${ }^{5}$ Epididymal involvement occurs close to the lesion in case of malignancy, whereas smooth calcification of tunica albugens with septate pyocele will favour tuberculous orchitis. ${ }^{8}$ Another important differential is torsion, which can be differentiated with altered position and absent vascularity of testis. ${ }^{1}$

\section{Learning points}

Tuberculous epididymo-orchitis can present with indolent course with normal levels of inflammatory markers.

- Ultrasound patterns of tuberculous epididymo-orchitis are diffuse or nodular enlarged hypoechoic testis and epididymis. Involvement of testis and epididymis indicates infective aetiology.

- Doppler finding in tuberculous epididymis is mildly increased vascularity, compared with markedly increased vascularity in pyogenic causes.
Contributors All authors have drafted the article, edited the article and reviewed the images. All the authors have contributed equally for the article.

Funding The authors have not declared a specific grant for this research from any funding agency in the public, commercial or not-for-profit sectors.

Competing interests None declared.

Patient consent for publication Obtained.

Provenance and peer review Not commissioned; externally peer reviewed.

\section{ORCID iDs}

Dhilip Andrew http://orcid.org/0000-0002-6154-3063

Karthik Shyam http://orcid.org/0000-0003-0998-9604

\section{REFERENCES}

1 Merchant S, Bharati A, Merchant N. Tuberculosis of the genitourinary system-Urinary tract tuberculosis: renal tuberculosis-Part I. Indian J Radiol Imaging 2013;23:46.

2 Yadav S, Singh P, Hemal A, et al. Genital tuberculosis: current status of diagnosis and management. Trans/ Androl Urol 2017:6:222-33.

3 Rodriguez-Takeuchi SY, Renjifo ME, Medina FJ. Extrapulmonary tuberculosis: pathophysiology and imaging findings. Radiographics 2019;39:2023-37.

4 Li Y, Mongan J, Behr SC, et al. Beyond prostate adenocarcinoma: expanding the differential diagnosis in prostate pathologic conditions. Radiographics 2016;36:1055-75.

5 Drudi FM, Laghi A, lannicelli E, et al. Tubercular epididymitis and orchitis: US patterns. Eur Radiol 1997;7:1076-8.

6 Tsili AC, Tsampoulas C, Giannakis D, et al. Tuberculous epididymo-orchitis: MRI findings. Br J Radiol 2008;81:e166-9.

7 Muttarak M, ChiangMai WN, Lojanapiwat B. Tuberculosis of the genitourinary tract: imaging features with pathological correlation. Singapore Med J 2005;46:568-74.

8 Nepal P, Ojili V, Songmen S, et al. "The Great Masquerader": Sonographic Pictorial Review of Testicular Tuberculosis and its Mimics. J Clin Imaging Sci 2019;9:27.

Copyright 2020 BMJ Publishing Group. All rights reserved. For permission to reuse any of this content visit

https://www.bmj.com/company/products-services/rights-and-licensing/permissions/

BMJ Case Report Fellows may re-use this article for personal use and teaching without any further permission.

Become a Fellow of BMJ Case Reports today and you can:

- Submit as many cases as you like

- Enjoy fast sympathetic peer review and rapid publication of accepted articles

- Access all the published articles

- Re-use any of the published material for personal use and teaching without further permission

Customer Service

If you have any further queries about your subscription, please contact our customer services team on +44 (0) 2071111105 or via email at support@bmj.com.

Visit casereports.bmj.com for more articles like this and to become a Fellow 